\title{
Russian Verse Studies after Gasparov
}

\section{Vera Polilova*}

\begin{abstract}
This article discusses the most important results and materials presented at the Verse Studies section of Gasparov Lectures 2007-2019, an annual conference held in Moscow every April since 2007 in memory of the prominent Russian scholar Mikhail L. Gasparov (1935-2005). It aims to present the current state of affairs in Russian verse studies, to sum up some of their recent achievements, to identify the main controversies that act as their growth points, and to highlight the most promising areas of current research into versification.
\end{abstract}

Keywords: Russian verse studies, Gasparov Lectures 2007-2019, issues in verse study

\section{Introduction}

On April 13, 2020, the greatest Russian verse scholar of the twentieth century, Mikhail Gasparov (1935-2005), would have turned 85. His colleagues - verse scholars, literary historians and classical philologists - planned to celebrate this date during the sessions of the Gasparov Lectures, a conference held every April since 2007 in memory of the eminent scholar. Like most other public events around the world, Gasparov Lectures 2020 were cancelled due to the pandemic, along with their Verse Studies section, a central discussion forum for topical issues in Russian verse studies in recent years. ${ }^{1}$ However, we can take advantage of this forced hiatus, to assess the progress made by Russian verse studies in the 15 years since Gasparov's passing.

The following survey is based on materials from the Verse Studies section of Gasparov Lectures 2007-2019 (see Belousova 2009; Golovastikov 2011a, 2011b, 2013; Polilova, Levashov 2013; Polilova 2014; Polilova, Levashov 2016, 2017; Polilova 2018; Polilova 2019; Polilova, Skulacheva 2021). It aims to present the current state of affairs in Russian verse studies, to sum up some of their recent achievements, to identify the main controversies that act as their growth points, and to highlight the most promising areas of research. Some

* Author's address: Vera Polilova, Institute of World Culture, Lomonosov Moscow State University, 1-51 Leninskie Gory, room 854, Moscow 119991, Russia. E-mail: vera.polilova@gmail.com.

1 After this article had already been completed, Gasparov Lectures 2020 were held in a scaleddown format between September 21 and 26. - Editors' Note. 
of the results presented and discussed here has already been published (in such cases, we provide the respective references). However, for various reasons, a substantial part of them has hitherto not taken shape in the form of books or individual articles. This is true of some of the most topical issues and hypotheses, discussions, critique, and debates that revolve around them. We will devote particular attention to this invisible side of the academic process.

Despite the variety of topics and approaches to verse studies presented at the meetings of the Gasparov Lectures that we will outline here, for most of their participants, the unifying research platform is represented by inductive statistics and probability-based analysis elaborated in the classical studies by Andrei Belyi, Boris Tomashevsky, Sergei Bobrov, Kiril Taranovsky, Andrei Kolmogorov, and Mikhail Gasparov himself. Therefore, the object of analysis, the conceptual apparatus, and the methodology are common to scholars of different generations working with a variety of verse material. An important feature of this research tradition is its historiographical nature manifested in researchers' attention to the works of the pioneers of verse studies and the theoretical and methodological principles formulated in these works (with varying degrees of accuracy). Another characteristic trait of present-day Russian verse theory is its constant striving for a systematization of its conceptual and terminological apparatus. It seems fair to say that Russian verse studies develop cyclically, re-actualizing and problematizing their legacy at every stage. Today, the entire conceptual baggage inherited from formalism and structuralism is subject to such re-actualization. This even applies to some research strategies that had been, it seemed, completely abandoned (for example, there has been a revival of interest in "tactometric theory", see below).

Anticipating our conclusion, one can say that - thanks to the revision of everything that had been done - Russian verse studies are gradually breaking out of a strategic impasse; the feeling of "all has been said and done" turned out to be erroneous.

Gasparov's tetralogy (Contemporary Russian Verse. Metrics and Rhythmics, 1974; An Outline of the History of Russian Verse, 1984¹, 2000²; Russian Verse in Commentaries, $1987^{1}, 1993^{2}, 2001^{3}$, and An Outline of the History of European Verse, $1989^{1}, 2003^{2}$, translated into English as A History of European Versification, 1996); see also Italian, 1993, and Czech editions, 2012), in the opinion of many scholars and general readers, has become a manifesto of the completeness of the edifice of Russian verse studies. In 1995, at the opening of the Slavic Verse international conference in Moscow, Gasparov himself said something of the kind and urged verse scholars to "think of expanding the discipline's field of vision, establishing a structural link between verse phenomena as such and those belonging to other levels within the structure of 
the poetic work, its phonetics, grammar, style, and semantics", since "the traditional four areas of verse studies (metrics, rhythmics, rhyme, and stanzas) are already so well-developed, that new revolutions are not to be expected there any time soon"; therefore, "[our] research methodology has already been elaborated, and now it is but a matter of time and capable graduate students" (the talk was revised into an article Gasparov 1996b: 5). This line of thinking was matched by Gasparov's own research strategy embodied by his books Metre and Meaning (1999) and Articles on Verse Linguistics (2004; co-authored with Tatiana Skulacheva).

Not all researchers, however, were ready to agree with Gasparov. In the introduction to his fundamental article "The European Metrical Fund of Russian Poetry of the 18th-20th Centuries", Mihhail Lotman argued:

[...] the author [i.e. Lotman] is far from assuming that the main problems of Russian versification have already been solved [and that] all that remains is to clarify some details, examine (using a well-established methodology) the material that has not yet been examined, and resolve some secondary issues concerning theoretical aspects. It seems that the situation is almost entirely the opposite. (Lotman 1995: 259)

\section{Lotman was echoed by Maksim Shapir:}

There is no denying that the achievements of Russian verse studies are indeed impressive, but the overwhelming majority of them are related to verse history (although here, too, there has recently been a tendency towards a radical revision of a whole series of ideas which until recently seemed unshakable [...]) [...] In the field of theory, the situation is much less favourable: with but a little exaggeration one can say that there still exists no theory of verse as a single scholarly discipline. (Shapir 2000: 76)

Lotman and Shapir proposed their own projects of a more general theory: Lotman, using the optics of generative metrics (see for example 1995, 1998, 2000), and Shapir (2000, 2015), developing the ideas of Russian formalists and structuralists (Yuri Tynianov, Maksim Kenigsberg, and Roman Jakobson). Shapir, who was among the most ardent partisans of quantitative verse studies, also wrote on the limitations of "exact" methods in verse theory (Shapir 2005; English translation: 2019); the article sparked a debate, already after Shapir's death (see Gladky 2007; Pertsov 2009).

It is with Shapir's name that the most remarkable controversies of the turn of the millennium are associated: e. g. regarding his hypothesis about the role 
of Empress Elizabeth's first name (Elizavéta / Elizavét) in the evolution of the rhythm of Lomonosov's iambus (i. e. involuntary and inevitable pyrrhic feet), and regarding his theoretical project (Shapir 2000: 9-128, 131-160). Lotman's generative approach provoked neither direct objections nor direct support in the Russian verse scholars' community in the 1980s and 1990s, but was acknowledged by Gasparov in his typology of versification systems presented in Gasparov 1989 (1996a) and paved the way for the reception of the generative approach by Russian verse scholars of the new generation.

The mid-2000s became a sad milestone in the history of the Russian verse studies. Gasparov's death was followed by the sudden and premature demise of Maksim Shapir (1962-2006), and, four years later, of Marina Krasnoperova (1940-2010), the creator of the theory of reconstructive simulation of versification. These losses significantly changed the academic landscape of Russian verse studies. In 2010, the scholarly discipline in question, orphaned and leaderless, celebrated its centenary jubilee (since the publication of Andrei Belyi's Symbolism).

At the 2010 international conference Russian Verse Theory: Centennial Results and Development Prospects, organized in Saint Petersburg by the students of Vladislav Kholshevnikov (1910-2000), ${ }^{2}$ scholars demonstrated the traditionally high standards of individual research and, at the same time, noted the need to systematize the accumulated material, revise the existing conceptual apparatus and present the results of their research in a form accessible not only to domain experts, but also to linguists, literary scholars, as well as students (Tverianovich 2011: 254). They also spoke of the need to create an academic history of Russian verse, a project yet to be launched. No terminological systematization has been achieved so far, although various groups of researchers have begun to work in this direction (Pilshchikov 2017a; English translation: Pilshchikov 2021a).

In recent years, independent verse scholars and a number of verse study groups have been active in Russia, as well as several university seminars:

1) at Saint Petersburg University, led by Elena Khvorostianova, a student of Vladislav Kholshevnikov (through their efforts, a two-volume metrical guide to the poems of several Russian poets was published; see Khvorostianova 2008-2013),

2) at the Russian State University for the Humanities (which hosts several projects on the linguistics of verse), led by Tatiana Skulacheva,

3) at Orenburg State University, led by Svetlana Matiash, and

2 See the conference proceedings (Bogdanov, Khvorostianova 2010). 
4) at the Higher School of Economics, led by Evgenii Kazartsev, a student of Marina Krasnoperova.

There are also two informal associations: a group of colleagues and former students of Maksim Shapir (including the coterie of contributors to the journal Philologica, 1994-2014) and Vladimir Plungian's group who are developing the Poetic Subcorpus of the Russian National Corpus.

In 2013, Vadim Baevsky died, and 2016 saw the death of Aleksandr Iliushin who had led seminars on poetics and verse theory at Smolensk State University and Moscow State University, respectively. Since 2010 (with some interruptions), the Vinogradov Institute of the Russian Language of the Russian Academy of Sciences (Moscow) has been hosting the Centre for Textology and Verse Studies (in 2019 renamed the Centre for Linguistic Textology and Computer Linguistic Verse Analysis) headed by Nikolai Pertsov. The Centre opens the floor to regular discussions of issues in the analysis of poetic speech.

\section{Gasparov Lectures 2007-2019: participants and topics}

At the turn of the millennium, before the birth of the Gasparov Lectures, only one regular verse studies conference had been held in Russia, the Slavic Verse triennial (since 1995), organized after Gasparov's death by Tatiana Skulacheva (the most recent proceedings: Prokhorov, Skulacheva 2009, 2012; Skulacheva 2017a, 2017b). The emergence of a new annual conference changed the rhythm and atmosphere of verse scholars' meetings: whereas at Slavic Verse researchers tried to present the results of large and completed projects, Gasparov Lectures offered ample opportunities for discussing materials in a "work in progress" mode and allowed for longer discussions. Gasparov Lectures differ from Slavic Verse in their more "parochial" format, with most of the participants being researchers from Moscow and Saint Petersburg.

Since 2007, the number of speakers has grown from 7 to 27 (in 2019). Over the years, the range of topics discussed has expanded as well. In addition to research within the framework of traditional sections of verse studies (metrics, rhythmics, stanzas, comparative metrics, linguistics of verse, poetic syntax, phonics, verse semantics, etc.), now participants present and discuss talks devoted to quantitative and automated methods in the study of text, the psychology and neurophysiology of perception as applied to verse, the acoustic analysis of recited poetry, etc. 
The distribution of talks by topic (see table below), hard as it is to unequivocally assign some talks to one group or another, reveals certain important tendencies.

Table 1. Distribution of talks by topic (the Verse Studies section of Gasparov Lectures, 2007-2019)

\begin{tabular}{|l|r|}
\hline Rhythmic typology & 22 \\
\hline History of Russian verse & 18 \\
\hline $\begin{array}{l}\text { Digital methods and computational tools for } \\
\text { linguistic and prosodic analysis of verse }\end{array}$ & 16 \\
\hline Rhythmical effects, expressive features of rhythm & 15 \\
\hline Comparative metrics & 15 \\
\hline Linguistics of verse & 14 \\
\hline Analysis of individual poetic texts & 13 \\
\hline & 11 \\
Research methods of studying verse & formal approaches) \\
\hline Underresearched non-Russian systems of & 8 \\
versification & 7 \\
\hline History of verse studies & 6 \\
\hline Verse semantics & 5 \\
\hline Stanzas & 5 \\
\hline Recited poetry & 5 \\
\hline Rhyme and euphony & 3 \\
\hline General verse theory & 3 \\
\hline Poetic syntax & 12 \\
\hline Metrical prose & 179 \\
\hline Other & 12 \\
\hline Total & 1 mathematical or \\
\hline
\end{tabular}

As apparent from the table, there has been little to no discussion on general verse theory. In the 13 years, there have only been three talks of this type, all featuring analysis, criticism, or interpretation of Shapir's theory of verse (talks in 2007, 2008, 2017). The issues of rhyme, sound organization of verse, and metric repertoire have been of marginal interest to the participants. Most scholarly 
activity seems to have revolved around rhythm factors and the development of a rhythmic typology of "non-classical" metres (i.e., non-syllabotonic / nonsyllabic-accentual metres), mainly the so-called dolnik and taktovik (meters with a variable length of the inter-ictic interval in a verse line). In dolniks, the amplitude of variation of inter-ictic intervals equals one (the inter-ictic intervals can be either monosyllabic or disyllabic). In taktoviks, the amplitude of variation of inter-ictic intervals equals two (the inter-ictic intervals can be monosyllabic, disyllabic, or trisyllabic) (Liapin, Pilshchikov 2015: 60).

A large group of talks classified as "Comparative metrics" has also dealt mainly with issues of rhythmic organization of texts in various languages, and those dealing with the analysis of individual poems were often focused on their rhythmic peculiarities (the commonest methodology consisting in the investigation of texts' rhythmic features in their complex interaction with the author's style, genre and composition). The number of talks on the verse linguistics has also been stably high. Among other topics of undying interest, one might highlight the development of computer analysis tools.

Below, we give a description of the results presented over the years at the Gasparov Lectures, related to the following research areas:

1) rhythmic typology and the study of rhythmical effects,

2) studies of the rhythm of the Russian iambic verse,

3) analysis of poetic syntax.

In addition, we will summarize the discussion of general verse theory that saw no major breakthroughs, but is particularly illustrative of the set of contemporary theoretical premises used by Russian poetry scholars.

Most of the talks, as can be seen from the table, were predictably devoted to various issues of the history of Russian verse, but a general account here is hardly possible, given the extreme variety of topics. Suffice it to mention special talks dedicated to the verse of seventeenth-, eighteenth-, nineteenthand twentieth-century Russian poets, such as Simeon Polotsky, Aleksandr Sumarokov, Mikhail Lomonosov, Evgenii Baratynsky, Kornei Chukovsky, Vladimir Pozner, Velimir Khlebnikov, Joseph Brodsky, Konstantin Balmont, Marina Tsvetaeva, Anna Akhmatova, and many others. Among this multitude of talks, particular mention should be made of Svetlana Matiash's fundamental study of Russian free iambic verse in the eighteenth and nineteenth centuries, culminating with the publication of a dedicated monograph (Matiash 2011). 


\section{Talks and discussions}

\subsection{Verse Theory}

As mentioned above, issues of general verse theory were discussed in connection with Shapir's theory of verse. It is based on the conception of verse viewed as a system of pervasive compulsory paradigmatic segmentations, which structure the texts' additional fourth dimension (in addition to the speech, linguistic and semiotic dimensions) and act as a unifying factor for segments that are sometimes strikingly different from each other in their length, grammar, and semantics (Shapir 2000: 36-75, 81-83; see also Belousova, Polilova 2015). According to Shapir, verse segmentations are compulsory because they are pre-ordained by the author's will, which is objectively expressed and cannot be ignored by the recipient; furthermore, they are consistent and paradigmatic: they form the rhythmic units belonging to the same level which are correlated with one another as variants of a single invariable. Shapir formulated his concept gradually, analyzing the theoretical works of poetry scholars of the 1920s (noting ideas which would corroborate his new theory), ${ }^{3}$ interpreting unusual verse forms and criticizing his contemporaries' and predecessors' definitions and formulations (in particular, Boris Bukhshtab's theory of double segmentation (Bukhshtab 1973: 110-111) and Tomashevsky's and Gasparov's definitions, according to which verse is "artistic speech phonically divided into relatively short segments which are perceived as comparable and commensurable" (Gasparov 1972: 197; 2001 [1993]: 6). The discussion of Shapir's theory was partly conditioned by its polemical presentation: for example, Sergei Kormilov, in 2008, devoted his talk at the Gasparov Lectures to the defense of Gasparov's formulations ("Where Shapir Was Wrong in Criticizing Gasparov's Theoretical Postulates as a Verse Scholar"), while Igor Pilshchikov and Nikolai Pertsov ("On Shapir's Concept of Verse", 2007) and Anastasia Belousova ("On Shapir's Concept of Verse Paradigmatics", 2017) used Shapir's theory to explore texts that were usually thought to elude analysis in the framework of verse studies.

These talks and discussions have repeatedly raised the issue of the psychological component of the distinction of verse $v s$. prose. Shapir himself was

\footnotetext{
3 Shapir's definition of verse is most closely related to Maksim Kenigsberg's conjectures on the nature of verse, as well as to Jakobson's definition of the poetic function (Shapir 2015: 346-383, 389-394): "The poetic function projects the principle of equivalence from the axis of selection into the axis of combination. Equivalence is promoted to the constitutive device of the sequence" (Jakobson 1960: 358).
} 
inclined to draw the boundaries as rigorously as possible, and the reliance on the reader's individual perception was not part of his phenomenological stance. Nevertheless, contemporary scholars of verse believe that such reliance is latently present in his theoretical constructs (Dobritsyn 2007: 503-505). Suggestions were made as to using a psychological experiment in the more difficult cases (for example, free verse or "feigned prose", mnimaja proza), when the definition of the invariant, and indeed the very answer to the "verse or prose" question, is unclear. Tatiana Skulacheva believes that Shapir and Gasparov attempted to define the same thing, namely, "a concept, intuitively felt but still not amenable to a strict linguistic description, that implies a psychological equality or balance between verse lines (Gasparov), reminiscent of the equality of members of a paradigm in language (Shapir)" (Skulacheva, Buiakova 2010: 38 fn. 1).

It can be said that, at present, we see maintenance of the status quo in Russian verse studies: many scholars prefer not to delve into general theoretical issues at all, others remain faithful to Gasparov's definitions, while a third group (primarily Shapir's closest colleagues and students who have attended his verse study seminar) rely on the provisions of Shapir's theory, often recognizing the need of a further clarification and development of his logic.

It seems that, in recent years, the most productive research has been not in the field of the theoretical definition of verse as such, but in the development of constructive (i.e. practical) definitions of the constituent elements of Russian verse: versification systems, poetic metres and their specific varieties, and poetic rhythm and rhythmical types of specific metres (see Pilshchikov 2017a, 2021a). The search for constructive definitions of the phenomena involved in Russian verse have primarily developed in connection with practical tasks, such as the automatic diagnostics of verse metre and the automatic recognition of rhythmical forms (ibid.; compare Pilshchikov, Starostin 2015).

\subsection{Rhythmic Typology. Classification of Metres}

Multiple talks have been devoted to the classification of Russian metres and versification systems, the material employed usually consisting of samples of non-classical (i.e., non-syllabic-accentual) metres of the Symbolist poets, as well as Joseph Brodsky's versification, so far defying a strict versological description and causing significant difficulties and disagreements in the interpretation of its individual specimens.

Time and time again, and from vastly different positions, the participants discussed the problem of distinguishing between different types of dolniks; 
between dolniks and taktoviks; taktoviks and mixed metres; free dolniks with unstressed ictuses and taktoviks; and - last but not least - taktoviks and dolniks "formed on the basis of binary metres" (with a predominance of monosyllabic iner-ictic intervals), which are uncommon to Russian poetry, unlike the more common taktoviks and dolniks "formed on the basis of ternary metres" (with a predominance of disyllabic iner-ictic intervals), ${ }^{4}$ as well as questions of the genesis of all these verse types. In 2014, Sergei Liapin devoted a special talk to the confusion reigning in current Russian verse nomenclature ("Evolution of Gasparov's Concepts of Dolnik and Taktovik"). In 2015, Kirill Korchagin presented a talk on Gasparov's concept of "a dolnik on the basis of binary metres" and discussed the peculiarities of this metre. Having analyzed the texts most likely to fall into the category of dolniks based on binary metres extracted from the Poetic Subcorpus of the Russian National Corpus, he found that they failed to demonstrate a sufficiently stable rhythmical type (poems by Leonid Martynov, Sergei Petrov, Igor Chinnov, and others). Tsvetaeva's dolnik on the binary (iambic) basis, possibly related to the German dolnik, were examined and allocated to a special group in Liapin's 2013 talk "Russian Hemiiambs and their European Analogues"; the ad hoc term "hemi-iambs" was suggested based on a $40 \%$ concentration of iambic lines in Tsvetaeva's dolnik poems (Liapin, Pilshchikov 2015: 73-77). In her 2017 talk, Vera Polilova spoke about the practical impossibility of using Gasparov's accepted definitions to distinguish unambiguously between dolniks with skipped ictic stresses, on the one hand, and taktoviks, on the other. She also proposed to no longer count Konstantin Balmont's experimental rhythm (the so-called "interrupted lines", preryvistye stroki) among 4-ictus taktoviks; she demonstrated that this type of verse was built on hemistichs of classical binary and ternary syllabic-accentual metres (Polilova 2017).

The typology of three principal types of the three-ictus dolnik by Russian poets introduced by Gasparov ("Esenin's type" with predominant forms I and III, "Gumilëv's type" with predominant forms III and II, and "Tsvetaeva's type", in which forms III and V prevail, see Gasparov 1968: 100-102; 1974: 241-242) was also refined on the basis of a corpus-dependent approach. Thus, in 2016, Aleksander Levashov spoke about his research into Sergei Esenin's three-ictus dolnik, conducted jointly with Liapin, Igor Pilshchikov, Alexander Prokhorov, and Anatoly Starostin. The researchers used a corpus-dependent approach to distinguish between dolniks and ternary metres and demonstrated the fallaciousness of the view that Esenin's dolnik is a transitional metrical form

4 Gasparov's terms: “dol'niki na dvuslozhnoi osnove" and "dol'niki na trekhslozhnoi osnove". 
between ternary metres and "Gumilëv's" and "Tsvetaeva's" more formalized types of dolnik (for preliminary results see Pilshchikov, Starostin 2015: 100101). Levashov and Liapin achieved important results in the study of Brodsky's dolnik: in a series of talks $(2010,2012,2013)$, elements of a new metric classification of Brodsky's texts were presented, based on rhythmic analysis, splitting apart some poetic forms previously lumped together. In particular, a separate metric type was identified, the basis of which is a line consisting of two segments of a three-ictus dolnik (Dk3 + Dk3; i.e. segmented dolnik, see Liapin 2011). Brodsky created it in the late 1960s and used it in all his subsequent oeuvre (that is, for more than a quarter of a century).

Yuri Orlitsky worked on the problem of the distinction between Brodsky's so-called "free blank accentual verse" and vers libre (his 2008 talk; see Orlitsky 2012). In 2014, Levashov and Prokhorov conducted a new statistical study of the samples of unrhymed accentual verse identified by Orlitsky, analyzing 25 of Brodsky's poems in terms of inter-stress interval distribution statistics. The researchers determined the correlation coefficients for different types of interstress intervals and identified two groups of poems. The first group includes texts, in which mono- and disyllabic inter-stress intervals prevail, whereas 0 - and 3-syllable intervals are avoided (in this group, 4- and 5- syllable interstress intervals are allowed, as well as 6- and 7-syllable intervals which are, however, rare). In the second group, the number of 0 - and 3-syllable interstress intervals avoided in the first group is greater. It turns out that the poems that fall into different groups are also chronologically remote from each other (see Levashov, Prokhorov 2016).

In discussions of "non-classical" (i. e. non-syllabotonic) metres at the meetings in various years, a frequent point of argument was the possibility of skipping metrical stresses in strong positions and determining the place of these unstressed ictuses (and indeed the very possibility of talking about ictuses in the dolnik and taktovik). In his 2017 talk "Beyond the Dolnik Verse': Unstressed Ictuses and Extra-schematic Stresses in Russian Accentual Verse", Igor Pilshchikov proposed to use the concept of ictus (and therefore metre) when analyzing not only dolniks and taktoviks, but also accentual verse. For a number of colleagues, Pilshchikov's very idea verged on absurdity. Many, following Gasparov, consider accentual verse to be purely tonic, that is, one where the range of fluctuations in the length of the inter-stress intervals is so great that it eliminates the very opposition between weak and strong positions. Pilshchikov believes that even in accentual verse (e.g. Mayakovsky's), the "interaction between rhythm and metre" is preserved, that is, there exist both extrametrical (extra-schematic) stresses on metrically unstressed syllables and unstressed ictuses - the fact which actually was never denied by 
Gasparov, who, however, preferred to refrain from far-reaching conclusions on the subject (see Pilshchikov 2021b; compare Pilshchikov 2017b, a follow up talk at Frontiers in Comparative Metrics 3 in Tallinn).

Another question raised more than once is that of the applicability of the concept of caesura to non-classical verse. When interpreting various poets' non-classical metres, researchers are faced with the fact that verse lines tend to be divided into two halves. It is not entirely permissible to refer to these metres as "caesuraed" according to the established Russian terminology; in Russian verse theory, a caesura is defined as a constant word boundary at a certain position of the line (usually after a specific foot). In the non-classical texts under consideration, the syllable length of the line is not constant and, accordingly, the position of the word boundary fluctuates (causing inconsistent augmentation or truncation). For such a caesura-like word boundary, the term "quasi-caesura", proposed by Vadim Semenov (2010), gained immediate traction. Kirill Korchagin proposed the concept of "derivational caesura" in his talk "Dolnik and Caesura: Stating the Problem" presented at the 2011 conference and in the unpublished PhD thesis Caesura in Russian Verse from the Eighteenth Century to the First Quarter of the Twentieth Century (2012). This term refers to the so-called "derivational model" of accentual verse developed by Vladimir Plungian and Kirill Korchagin himself (Korchagin 2020; see also Semenov 2013). From the point of view of this theory, specific lines of dolnik-like and taktovik-like texts are viewed as derived from some regular and conventional syllabic-accentual pattern by way of transformation. In a follow-up discussion on the issue of the caesura, it was also noted (Levashov, Liapin) that an exclusive application of the notion to syllabic-accentual verse is not entirely reasonable: Gasparov had already applied this term to non-classical Russian verse, such as Russian galliambs (2001 [1993]: 144; cf. Dobritsyn 1993: 307).

A more exhaustive idea of Plungian and Korchagin's approach to the dolnik can be obtained from Korchagin's 2017 talk ("The Dolnik as a Static Object and a Dynamic Procedure: The Tactometric Procedure and Mikhail Gasparov", see Korchagin 2020). The essence of the proposed approach can be reduced to the distinction between three entities:

1) the basic (initial) metric structure,

2) the real (observed) metric structure,

and 3) the rules of the transition from (1) to (2).

Methodologically, this approach does not differ from most of the models adopted in conemporary linguistics (the only difference being the material). Accordingly, it is proposed to regard the dolnik as "a dynamic entity". According to Korchagin, this understanding is also close to Gasparov's ideas: 
if one can speak of a dolnik on the binary or ternary basis, then there is an implicit set of procedures enabling the transition from an iambic/trochaic/ dactylic/anapaestic/amphibrachic line to a corresponding dolnik line. These procedures transform syllabic-accentual verse into dolnik by means of:

1) syncope, the elimination of the syllable in the weak position of the foot (creating a "leimma", in Georgii Shengeli's terms, i.e. (usually) a transformation of a disyllabic interval into a monosyllabic one in a line of ternary metre);

2) reduction of the syllable in a strong position with the loss of the ictus occupying that position;

3) reaccentuation;

4) extension of the foot; etc. (see Korchagin 2017; also Plungian 2005, 2014 etc.).

This approach is close to generative metrics and revives the reasoning of the "tactometric theory" proposed by Aleksandr Kviatkovsky in the 1920s (Korchagin 2020). Lively debates took place during the discussion of this talk and other contributions with a similar approach to the problem of verse forms with a fixed number of ictuses and a fixed diapason of variation of unstressed syllables in the inter-ictic interval (for example, Plungian's 2010 talk "Nochami edet skvoz' zybkij son' ['Rides Through a Fluid Dream at Night']: On the Metrics of Igor Chinnov's Poem"). In particular, Sergei Liapin and Marina Akimova spoke of the frequent impossibility of an unambiguous choice between a binary or ternary basis for a specific dolnik text; moreover, a "dynamic" or "derivational" interpretation makes it impossible to create a rigorous rhythmic typology: instead of working with the real rhythmical structure of a text, the researcher is urged to search for its deeper structure which is unknown in advance. It remains unclear to other scholars of verse how to limit the number of procedures. Discussions on these issues have not been reflected in articles published in recent years.

In 2018 Liapin proposed another approach to dolnik ("On the Problem of the Poetic Description of the Russian Dolnik"). He explained the popularity of the dolnik in the twentieth century and its gradual transformation, in Gasparov's words, into the "sixth classical Russian metre" (Gasparov 2000 [1984]: 308), by the fact that this metre is constructed with emphasis not only on the two-syllable and three-syllable foot (i.e. the dolniks on the binary metre basis or ternary metre basis) but also tetrasyllabic feet (paeans) and pentasyllabic feet (hyper-paeans). According to Liapin's assumption, dolnik is a special form of syllabic-accentual verse, and many dolnik texts should be regarded as poems based on a pentasyllabic rhythm. As a striking example of such verse, Liapin analyzed the lines of Tsvetaeva's Perekop (1928-29). They are 
akatalectic and, therefore, a pentasyllabic inertia is clearly perceptible in them. According to Liapin, without considering the phenomenon of tetrasyllabic and pentasyllabic feet, it is impossible to understand the evolution of the Russian dolnik, and its rapid establishment in the metrical canon is bound to remain an insoluble mystery, just like the failure of its development in the nineteenth century. Arguably, the dolnik on the pentasyllabic basis crystallized gradually. It emerged in folk poetry, then evolved in Koltsov's experiments with a hyperpaeanic metre ("penton III", a pentasyllabic line/foot with a stress on the third syllable) and eventually flourished in the poetry of the Acmeists, who succeeded in combining the existing trends and launched the "metro-rhythmical wave" that is characteristic of the modern Russian dolnik.

A review of the talks presented at Gasparov Lectures on the issues of rhythmic typology shows unequivocally that the non-classical Russian metres - the dolnik, the taktovik and accentual verse - have not yet been adequately investigated. The nomenclature Gasparov proposed in 1974 underwent significant (but not explicitly articulated) changes in his subsequent works but it does not allow for a consistent description of contemporary diversity of Russian non-classical metric forms.

Obviously, the recourse to computer-aided statistical analysis, especially the use the corpus-statistical approach, has led to important results, but there is still much to be done in the identification of relevant metric features. The available statistical data needs to be expanded, which will definitely help make the existing definitions more precise, yet, at the same time, will hardly solve all of the problems, as data gathered without relying on a working hypothesis often turns out to be useless (as is the case with the existing studies of Brodsky's or Balmont's poems, where statistics collected without a clear understanding of the rhythmic structure has for years obscured the visibility of hemistichs and impeded an accurate analysis of the rhythm, which lead to incorrect metric interpretations).

To sum up, practical work in verse studies should go hand in hand with theoretical work. When analyzing verse, it is necessary to identify its rhythmical impulse, while a mere accumulation of data concerning stressed and unstressed syllables in a line is insufficient.

\subsection{Research into Russian lambus. Criticism of Taranovsky's Autonomous Rhythmic Laws. Issues in verse modelling}

In the case of Russian non-classical metrics (implicit and a-posteriori metrics, to quote Mihhail Lotman 2008), the data accumulated over a century are not the result but rather the beginning of research. Surprisingly enough, studies of 
classical Russian metres, allegedly by now explored "inside out", have revealed new facts, especially as regards their rhythm.

First of all, even the most meticulously prepared statistics do not create an objective picture by themselves, since the sample analyzed may not be representative. The rhythm is influenced by many factors: the genre characteristics of the text, its length, the stanzaic form, the number of enjambments, and the part-of-speech content of the lines. Each of these parameters affects the obtained results, and, with data from different texts combined, a distortion and averaging of the results inevitably occur.

Liapin's 2015 talk "On the Failure of the 'Autonomous Laws of Versification"” criticized Taranovsky's law of "regressive accentual dissimilation" and outlined an alternative conception of the rhythmic development of Russian iambic tetrameter from the eighteenth through the twentieth centuries. Liapin's key claim was that alternating rhythm emerged as a consequence of the syntactic features of rhythmic forms III and VI of Russian iambic tetrameter $(\mathrm{xX} \underline{x} \mathrm{x} X x \mathrm{X}(\mathrm{x})$ and $\mathrm{x} \underline{\mathrm{x}} \mathrm{XX} \underline{\mathrm{x}} \mathrm{xX}(\mathrm{x})) .{ }^{5}$ He presented the development of the metre as a chain of successive revolutions:

1) the rejection of full stress in Mikhail Lomonosov's verse;

2) elimination of Form III, unusual for a colon with final stress (in Russian, it is more frequently stressed in the middle), due to Ivan Krylov's rejection of inversions;

3) the actualization of Form VI in Vasilii Zhukovsky's verse, and 4) the final transition to "natural" syntax and the corresponding rhythm in Vladislav Khodasevich's iambs.

In 2015, Levashov presented additional arguments in favour of changes in the frequency of four-foot iambic Forms III and VI being caused by the rejection of inversions at the turn of the nineteenth century. A year later, Liapin presented new evidence in favour of the view that Russian iambic tetrameter was governed not by special verse laws, but by general speech tendencies. According to Liapin's data, in twentieth-century verse, compared to nineteenth-century verse, the frequency of rhythmic Forms III, VI, and VII increases at the expense of Forms I and IV. At the same time, the frequency of Forms VI and VII grows proportionally, so that we can classify the rhythm profile as neither $N$-shaped nor $U$-shaped. Liapin also noted that the distribution of rhythmic forms is identical both in twentieth-century verse and in random iambic lines generated by the Yandex Autopoet online robot that creates poetry based on users' search queries. According to Liapin, this

\footnotetext{
5 For the accepted classification of rhythmic Forms see, for example, Dobritsyn 2016: 36.
} 
is how the process of convergence of iambic verse with natural speech was completed - the process that had been ongoing for three centuries. In other words, Liapin continues, the basis of the evolution of the rhythm of the iambic tetrameter from the eighteenth to the twentieth century lies not in the transition from a $U$-shaped rhythm to an alternating $N$-shaped form, but in the consistent convergence of this poetic metre and everyday speech habits (the results of this study are summarized in Liapin 2016 and 2020). Objections to Liapin's claims were raised in Mikhail Lotman's talk "Are There Autonomic Laws of Verse Rhythm?" presented at the Tallinn-based conference Frontiers in Comparative Metrics 3 (see the abstract Lotman 2017 and the subsequent publication Lotman 2019), frequented by many Gasparov Lectures regulars. In the ensuing discussion, Liapin accepted some of Lotman's counter-arguments, which he then stated explicitly in his later publications.

Thus, in recent years, a completely new account of the history of the development of the rhythm of the most popular Russian iambic metre was proposed. Evidently, it will be a while before it is properly comprehended and accepted by the academic community. The discussions following the talks on Taranovsky's rhythmic laws have been invariably lively: some of the listeners fully accepted the revolutionary conclusions, while Alexander Prokhorov and Evgenii Kazartsev firmly disagreed with them and voiced their objections.

Ultimately, the disagreement centres around the question as to the principal cause of Russian iambic tetrameter's rhythmic evolution from the "eighteenthcentury rhythm" to the "nineteenth-century rhythm" (has it evolved from verse rhythm towards natural speech rhythm or vice versa). Another issue is the kind of data that should be taken as the reference standard for "neutral" verse rhythm, i.e. a language-based model (Tomashevsky-Kolmogorov), a speechbased model (Kholshevnikov), or a model based on cognitive reconstructive simulation of versification (Krasnoperova).

The language-based model of verse (also known as the "theoretical-probabilistic" model) is computed by multiplying the "linguistic" probabilities of the words (or phrases unified by one stress) that fit in a line of a particular metre and particular length (this probability is defined by the sum of all possible combinations of rhythmic words/phrases in the metrical design). The speech-based model is defined differently: syntagmas (phrases with one or more stresses) that fit in a line of a particular metre and particular length are extracted from prose (they are called sluchajnye iamby, "random iambs", or samorodnye iamby "native iambs"). Marina Krasnoperova developed a model based on the principle that the choice of each rhythm-forming element (rhythmic word/phrase unified by one stress) in a verse line depends on its metrical position and rhythmic context 
(Krasnoperova 2000: 99-101; etc.; Krasnoperova, Kazartsev 2011; Kazartsev 2014; 2017: 129-133; 2019; 2020 etc.).

The challenge of comparing the results of the rhythmic analysis of specific texts with those of the different approaches and comparative data interpretation seems to be one of the most important issues in modern verse studies. The theoretical foundations and the very practice of the formation of these models should remain subject to discussion and mutually interested criticism.

\section{Conclusion}

Based on our review of the talks and discussions that have taken place at the verse studies section of Gasparov Lectures, we can single out the domains that are most popular today among Russian researchers and have shown the most promising results:

- Creation of a new paradigm for the description of the rhythm of Russian iambic tetrameter

- Rhythmic typology and the study of Russian non-syllabotonic versification

- Study of various aspects of the meaning of poetic forms (verse semantics)

- Analysis of the relationship between verse and language: rhythm and poetic syntax

- Comparative metrics

The first four directions of research were outlined above as succinctly as possible. The current state of affairs in comparative metrics in Russia will be described in a special paper. ${ }^{6}$

The study of Russian verse is an endeavour that unites researchers of several generations and academic schools from all over the globe. Scholars of Russian verse continue to make a significant contribution to this collective effort. The diversity of viewpoints, objects of research, methods and techniques is brought together by a shared underlying scholarly tradition.

What Russian verse studies lack today are new recapitulative book monographs that would take into account and summarize the results of the recent decades. The appearance of such works could help curb the inevitable trend toward "atomization" observable in scholarly research in the field and in

\footnotetext{
6 See Igor Pilshchikov, Vera Polilova. Comparative Verse Studies in Russia and Beyond (in press).
} 
general. In addition, among the traditional subfields of verse studies, euphony stands out as the most needy of further development (Georgii Vekshin is the only researcher persistently working in this area today; see, for example, Vekshin 2006 and 2012). The contradiction between the fundamental significance of this aspect of poetic speech and the extreme paucity of ongoing studies is particularly striking. ${ }^{7}$

\section{References}

Belousova, Anastasiia Sergeevna; Polilova, Vera Sergeevna 2015. Nenapisannaja stat'ja M. I. Shapira o "stikhakh na kartochkakh" L'va Rubinshtejna. In: Shapir, Maksim Il'ich. Universum versus: Jazyk - stikh - smysl v russkoj poezii XVIII-XX vekov. Vol. 2. Moskva: Jazyki slavjanskoj kul'tury, 483-495.

Belousova, Vera 2009. Gasparovskie chtenija-2009 (Moskva, 9-11 aprelja 2009 g.): Stikhovedenie. In: Novoe literaturnoe obozrenie 98, 409-412.

Bogdanov, Sergei Igorevich; Khvorostianova, Elena Viktorovna (eds.) 2010. Otechestvennoe stikhovedenie: 100-letnie itogi i perspektivy razvitija: Materialy Mezhdunarodnoj nauchnoj konferentsii 25-27 nojabrja 2010 g. Sankt-Peterburg. Sankt-Peterburg: Filologicheskij fakul'tet SPbGU.

Bukhshtab, Boris Yakovlevich 1973. Ob osnovakh i tipakh russkogo stikha. In: International Journal of Slavic Linguistics and Poetics 16, 96-118.

Dobritsyn, Andrei Aleksandrovich 1993. Gallijamb u Voloshina (v poiskakh semantiki metra). Russian Linguistics 17(3), 299-312. https://doi.org/10.1007/BF01838771

Dobritsyn, Andrei 2007. Les travaux sur la poésie russe de Maksim Šapir (25 août 1962 - 3 août 2006). Revue des études slaves 78(4), 495-506.

Dobritsyn, Andrei 2016. Rhythmic entropy as a measure of rhythmic diversity (The example of the Russian iambic tetrameter). In: Studia Metrica et Poetica 3(1), 33-52. https://doi.org/10.12697/smp.2016.3.1.02

Gasparov, Mikhail Leonovich 1968. Russkij trekhudarnyi dol'nik XX veka. In: Kholshevnikov, Vladislav Evgen'evich (ed.), Teorija stikha. Leningrad: Nauka, 59-106.

\footnotetext{
This publication was supported by Russian Science Foundation grant 19-78-10132. I am grateful to Sergei Liapin, Mihhail Lotman, Igor Pilshchikov, and Mikhail Oslon for their comments and suggestions.
} 
Gasparov, Mikhail Leonovich 1972. Stikh. In: Surkov, Aleksei Aleksandrovich (ed.), Kratkaja literaturnaja entsiklopedija, vol. 7. Moskva: Sovetskaja entsiklopedija, col. 197-198.

Gasparov, Mikhail Leonovich 1974. Sovremennyj russkij stikh. Metrika i ritmika. [Contemporary Russian Verse. Metrics and Rhythmics]. Moskva: Nauka.

Gasparov, Mikhail Leonovich 1989. Ocherk istorii evropejskogo stikha. [An Outline of the History of European Verse]. Moskva: Nauka.

Gasparov, Mikhail Leonovich 1993. Storia del verso europeo. Edizione italiana a cura di Stefano Garzonio. Bologna: Il Mulino.

Gasparov, Mikhail Leonovich 1996a. A History of European Versification. Translated by Gerald Stanton Smith and Marina Tarlinskaja. Edited by Gerald Stanton Smith and Leofranc Holford-Strevens. Oxford: Clarendon Press.

Gasparov, Mikhail Leonovich 1996b. Lingvistika stikha. In: Gasparov, Mikhail Leonovich; Skulacheva, Tatiana Vladimirovna (eds.), Slavjanskij stikh: Stikhovedenie, lingvistika i poetika: Materialy mezhdunarodnoj konferentsii, 19-23 ijunja $1995 \mathrm{~g}$. Moskva: Nauka, 5-17.

Gasparov, Mikhail Leonovich 2000 [1984]. Ocherk istorii russkogo stikha: Metrika. Ritmika. Rifma. Strofika. [An Outline of the History of Russian Verse: Metrics. Rhythmics. Rhyme. Stanzas]. Moskva: Nauka.

Gasparov, Mikhail Leonovich 2001 [1993]. Russkij stikh nachala XX veka v kommentarijakh [The Russian Verse of the Beginning of the 20th Century in Commentaries]. Moskva: Fortuna Limited.

Gasparov, Mikhail Leonovich 2012 [1999]. Metr i smysl: Ob odnom iz mekhanizmov kul'turnoj pamjati [Meter and Meaning: On one of the Mechanisms of Cultural Memory]. Moskva: Fortuna EL.

Gasparov, Mikhail Leonovich; Skulacheva, Tatiana Vladimirovna 2004. Stat'i o lingvistike stikha. [Articles on Verse Linguistics]. Moskva: Jazyki slavianskoj kul'tury.

Gasparov, Mikhail Leonovich 2012. Nástin dějin evropského verše. Překlad Robert Ibrahim, Alena Machoninová. Praha: Dauphin.

Gladky, Alexei Vsevolodovich 2007. O tochnykh i matematicheskikh metodakh v lingvistike i drugikh gumanitarnykh naukakh. In: Voprosy jazykoznanija 5, 22-38.

Golovastikov, Kirill 2011a. Gasparovskie chtenija-2010 (Moskva, RGGU, 15-17 aprelja 2010 g.): Stikhovedenie. In: Novoe literaturnoe obozrenie 107, 406-409. 
Golovastikov, Kirill 2011b. Gasparovskie chtenija-2011 (Moskva, RGGU, 14-16 aprelja 2011 g.): Stikhovedenie. In: Novoe literaturnoe obozrenie 112, 465-467.

Golovastikov, Kirill. 2013. Gasparovskie chtenija-2012 (Moskva, RGGU, 19-20 aprelja 2012 g.): Stikhovedenie. In: Novoe literaturnoe obozrenie 120, 439-444.

Jakobson, Roman 1960. Closing Statement: Linguistics and Poetics. In: Sebeok, Thomas A. (ed.), Style in Language. Cambridge, MA: MIT Press, 350-377.

Kazartsev, Evgenii 2014. Comparative Study of Verse: Language Probability Models. In: Style 48(2), 119-139.

Kazartsev, Evgenii Viacheslavovich 2017. Sravnitel'noe stikhovedenie: metrika i ritmika. Sankt-Peterburg: Izdatel'stvo RGPU im. A. I. Gertsena.

Kazartsev, Evgeny 2019. Probability and Cognitive Models of Verse Meter. In: Plecháč, Petr; Scherr, Barry P.; Skulacheva, Tatyana; Bermúdez-Sabel, Helena; Kolár, Robert (eds.), Quantitative Approaches to Versification. Prague: The Institute of Czech Literature of the Czech Academy of Sciences, 105-112.

Kazartsev, Evgeny 2020. Computer models of verse prosody. In: Elizarov, Alexander; Loukachevitch, Natalia (eds.), Proceedings of the Computational Models in Language and Speech Workshop, Kazan, Russian, November 12-13, 2020. (CEUR Workshop Proceedings 2780), 155-165. http://ceur-ws.org/Vol-2780/paper14.pdf

Khvorostianova, Elena Viktorovna (ed.) 2008-2013. Peterburgskaja stikhotvornaja kul'tura: materialy po metrike, strofike i ritmike peterburgskikh poetov, vol. I-II. Sankt-Peterburg: Nestor-Istorija.

Korchagin, Kirill Mikhajlovich 2017. Tipologija sistem stikhoslozhenija i metricheskij status dol'nika na dvuslozhnoj osnove. In: Zbornik Matice Srpske za slavistiku I Matica Srpska Journal of Slavic Studies 92, 707-728.

Korchagin, Kirill Mikhajlovich 2020. Derivatsionnaja teorija metriki: prolog. In: Kibrik, Andrej Aleksandrovich et al. (eds.), VAProsy jazykoznanija: Megasbornik nanostatej. Sbornik statej k jubileju V. A. Plungjana. Moskva: Buki Vedi, 99-104.

Krasnoperova, Marina Abramovna 2000. Osnovy rekonstruktivnogo modelirovanija stikhoslozhenija (na materiale ritmiki russkogo stikha). Sankt-Peterburg: Izdatel'stvo Sankt-Peterburgskogo gosudarstvennogo universiteta.

Krasnoperova, Marina; Kazartsev, Evgeny 2011. Reconstructive simulation of versification in comparative studies of texts in different languages (theoretical aspects and practice of application). In: Lotman, Maria-Kristiina; Lotman, Mihhail (eds.), Frontiers in Comparative Metrics. Bern [etc.]: Peter Lang, 97-120. 
Levashov, Aleksandr Mikhailovich; Prokhorov, Aleksandr Vladimirovich 2016. Statisticheskij metod klassifikatsii metrov neklassicheskogo russkogo stikha (na materiale tak nazyvaemogo "belogo aktsentnogo stikha" I. Brodskogo). In: Voprosy jazykoznanija 4, 112-133. https://doi.org/10.31857/S0373658X0001052-6

Liapin, Sergei Evgen'evich 2011. “Segmentnyj” dol'nik: k opisaniju metricheskikh novatsij Iosifa Brodskogo. In: Vestnik Moskovskogo universiteta. Serija 9: Filologija $6,36-46$.

Liapin, Sergei 2016. The Russian iambic tetrameter: The problem of description (Prolegomena to a new paradigm). In: Studia Metrica et Poetica 3(2), 99-127. https://doi.org/10.12697/smp.2016.3.2.04

Liapin, Sergei 2020. Russian Iambic Tetrameter: The Evolution of Its Rhythmic Structure. In: Studia Metrica et Poetica 7(2), 7-22. https://doi.org/10.12697/smp.2020.7.2.01

Liapin, Sergei; Pilshchikov, Igor 2015. "Ein Fichtenbaum steht einsam" and the typology of the Russian dolnik (following Osip Brik's, Boris Jarcho's and Andrei Fedorov's remarks on the Russian translations from Heine). In: Studia Metrica et Poetica 2(1), 58-80. https://doi.org/10.12697/smp.2015.2.1.03

Lotman, Mihhail 1995. Russkij stikh: osnovnye razmery, vkhodjashchie v evropejskij metricheskij fond. In: Pszczołowska, Lucylla; Urbańska, Dorota (eds.), Europejskie wzorce metryczne $w$ literaturach słowiańskich (Słowiańska metryka porównawcza VI). Warszawa: Instytut Badań Literackich, 259-340.

Lotman, Mihhail 1998. O sistemakh stikhoslozhenija (preimushchestvenno na materiale estonskogo i russkogo stikha). In: Trudy po znakovym sistemam 26, 201-255.

Lotman, Mihhail 2000. Russkij stikh: metrika, sistemy stikhoslozhenija, prosodika (generativnyj podkhod). In: Sign Systems Studies 28, 217-241. https://doi.org/10.12697/SSS.2000.28.12

Lotman, Mihhail 2008. Metre: The Unknown. In: Lotman, Maria-Kristiina; Lotman, Mihhail (eds.), Frontiers in Comparative Metrics: in memoriam Mikhail Gasparov: Conference abstracts, November 21-23, 2008. Tallinn: Tallinn University Press, $32-34$.

Lotman, Mihhail 2017. Are there autonomic laws of verse rhythm. In: Lotman, MariaKristiina; Lotman, Mihhail; Pilshchikov, Igor (eds.), Frontiers in Comparative Metrics 3. In memoriam Jaak Põldmäe. September 29-30, Tallinn: Tallinna Ülikool, 29. 
Lotman, Mihhail 2019. The semiotics of verse rhythm and comparative rhythmics: Vladimir Nabokov's and Jurgis Baltrušaitis's binary tetrameters from a typological perspective. In: Studia Metrica et Poetica 6(2), 74-101. https://doi.org/10.12697/smp.2019.6.2.03

Matiash, Svetlana Alekseevna 2011. Vol'nyj jamb russkoj poezii XVIII-XIX vv.: Zhanr, stil', stikh. Sankt-Peterburg: Filologicheskij fakul'tet SPBGU.

Orlitsky, Yuri Borisovich 2012. Belyj aktsentnyj stikh Iosifa Brodskogo. In: Prokhorov, Aleksandr Vladimirovich; Skulacheva, Tat'jana Vladimirovna (eds.), Slavjanskij stikh IX. Moskva: Rukopisnye pamjatniki drevnej Rusi, 117-124.

Pertsov, Nikolai Viktorovich. 2009. O tochnosti v filologii. In: Voprosy jazykoznanija $3,100-124$.

Pilshchikov, Igor 2017a. Ponjatija "stikh", "metr" i "ritm" v russkom stikhovedenii XX veka. In: Trudy Instituta russkogo jazyka im. V. V. Vinogradova 11: Slavjanskij stikh, 12-30.

Pilshchikov, Igor 2017b. Is there such a thing as "pure accentual verse" in Russian prosody? In: Lotman, Maria-Kristiina; Lotman, Mihhail; Pilshchikov, Igor (eds.), Frontiers in Comparative Metrics 3: in memory of Jaak Põldmäe. September 29-30, 2017. Tallinn University, Estonia: Conference abstracts. Tallinn: [Tallinn University], $33-35$.

Pilshchikov, Igor 2021a. The Concepts of "Verse", "Meter" and "Rhythm" in Russian Verse Theory. In: Forum Poetyki / Forum of Poetics (forthcoming).

Pilshchikov, Igor 2021b. "Po tu storonu dol'nika”: Bezudarnye ikty i sverkhskhemnye udarenija v russkom aktsentnom stikhe. In: Kritika i semiotica (forthcoming).

Pilshchikov, Igor; Starostin, Anatoli 2015. Reconnaissance automatique des mètres des vers russes: une approche statistique sur corpus. Traduit par Éliane Delente. Langages 199, 89-105. https://doi.org/10.3917/lang.199.0089

Plungian, Vladimir Aleksandrovich 2005. K evoljutsii russkoj metriki: nemonotonnaja sillabo-tonika. In: Toporov, Vladimir Nikolaevich et al. (eds.), Jazyk. Lichnost'. Tekst: Sbornik statej k 70-letiju T. M. Nikolaevoj. Moskva: Jazyki slavjanskikh kul'tur, 857-869.

Plungian, Vladimir Aleksandrovich 2014. Neklassicheskij stikh Lermontova: nekotorye detali. In: Uchenye zapiski Petrozavodskogo gosudarstvennogo universiteta 7, 40-51.

Polilova, Vera 2014. Gasparovskie chtenija-2014 (RGGU, 13-16 aprelja 2014 g.): Stikhovedenie. In: Novoe literaturnoe obozrenie 130, 409-419. 
Polilova, Vera 2018. Gasparovskie chtenija[-2017] (RGGU / NIU VShE, 19-22 aprelja 2017 g.): Stikhovedenie. In: Novoe literaturnoe obozrenie 150, 407-413.

Polilova, Vera 2019. Gasparovskie chtenija[-2018] (IVGI RGGU, 12-14 aprelja 2018 g.): Stikhovedenie. In: Novoe literaturnoe obozrenie 155, 420-430.

Polilova, Vera; Levashov, Aleksandr 2013. Gasparovskie chtenija-2013 (RGGU, 18-20 aprelja 2013 g.): Stikhovedenie. In: Novoe literaturnoe obozrenie 124, 414-422.

Polilova, Vera; Levashov, Aleksandr 2016. Gasparovskie chtenija-2015 (RGGU, 16-18 aprelja 2015 g.): Stikhovedenie. In: Novoe literaturnoe obozrenie 137, 382-388.

Polilova, Vera; Levashov, Aleksandr 2017. X Gasparovskie chtenija[-2016] (IVGI RGGU, 14-16 aprelja 2016 g.): Stikhovedenie. In: Novoe literaturnoe obozrenie $145,452-457$.

Polilova, Vera; Skulacheva, Tatiana 2021. XIII Gasparovskie chtenija[-2019] (RGGU, RANKhiGS, 15-20 aprelja 2019 g.): Stikhovedenie. In: Novoe literaturnoe obozrenie 167, 9-14.

Polilova, Vera 2017. O neklassicheskom stikhe Bal'monta: Ritmicheskaja struktura preryvistykh strok. In: Zbornik Matice Srpske za slavistiku / Matica Srpska Journal of Slavic Studies 92, 731-746.

Prokhorov, Aleksandr Vladimirovich; Skulacheva, Tatiana Vladimirovna (eds.) 2009. Slavjanskij stikh VIII: Stikh, jazyk, smysl. [Slavic Verse VIII]. Moskva: Jazyki slavjanskikh kul'tur.

Prokhorov, Aleksandr Vladimirovich; Skulacheva, Tatiana Vladimirovna (eds.) 2012. Slavjanskij stikh IX. [Slavic Verse IX]. Moskva: Rukopisnye pamjatniki drevnej Rusi.

Semenov, Vadim 2010. Polustishija v pozdnem neklassicheskom stikhe I. Brodskogo: kvazitsezura. In: Studia Slavica: sbornik nauchnyh rabot molodykh filologov IX. Tallinn: Institut slavjanskikh jazykov i kul'tur, 199-222.

Semenov, Vadim 2013. Rannij taktovik Bloka kak postmetricheskij stikh: (v zashhitu derivacionnoj modeli tonicheskoj metriki). In: Stat'i na sluchaj: sbornik k 50-letiju R. G. Lejbova [Digital edition]. Tartu. http://www.ruthenia.ru/leibov_50/Semenov.pdf

Shapir, Maksim Il'ich 2000. Universum versus: Jazyk - stikh - smysl v russkoj poezii XVIII-XX vekov. Vol. 1. Moskva: Jazyki russkoj kul'tury.

Shapir, Maksim Il'ich 2005. “Tebe chisla i mery net”: O vozmozhnostjakh i granitsakh "tochnykh metodov" v gumanitarnykh naukakh. In: Voprosy jazykoznanija 1, 43-62. 
Shapir, Maksim Il'ich 2015. Universum versus: Jazyk - stikh - smysl v russkoj poezii XVIII-XX vekov. Vol. 2. Moskva: Jazyki slavjanskoj kul'tury.

Shapir, Maksim Il'ich 2019. "For Thee There Is No Weight Nor Measure": The Possibilities and Limitations of "Exact" Methods in the Humanities. Translated by Craig Saunders. In: Journal of Literary Theory 13(1), 116-144. https://doi.org/10.1515/jlt-2019-0004

Skulacheva, Tatiana Vladimirovna (ed.) 2017a. Trudy Instituta russkogo jazyka im. V. V. Vinogradova 11: Slavjanskij stikh. [Slavic Verse].

Skulacheva, Tatiana Vladimirovna (ed.) 2017b. Trudy Instituta russkogo jazyka im. V. V. Vinogradova 14: Slavjanskij stikh. [Slavic Verse].

Skulacheva, Tatiana Vladimirova; Buiakova, Mariia Valerievna 2010. Stikh i proza: sochinenie i podchinenie. In: Voprosy jazykoznanija 2, 37-54.

Tverianovich, Kseniia Yurievna 2011. Mezhdunarodnaja nauchnaja konferentsija “Otechestvennoe stikhovedenie: 100-letnie itogi i perspektivy razvitija”. In: Vestnik Moskovskogo universiteta. Serija 9. Filologija 3, 250-254.

Vekshin, Georgii Viktorovich 2006. Ocherk fonostilistiki teksta: Zvukovoj povtor v perspektive smysloobrazovanija. Moskva: MGUP.

Vekshin, Georgii Viktorovich 2012. Rifma - vnutrennjaja rifma - alliteratsija. (Sillabotsentricheskij vzgljad). In: Prokhorov, Aleksandr Vladimirovich; Skulacheva, Tat'jana Vladimirovna (eds.), Slavjanskij stikh IX. Moskva: Rukopisnye pamjatniki drevnej Rusi, 152-164. 